\title{
The efficacy of Instagram on biology undergraduate students in University of Ilorin, Nigeria
}

\author{
Mulkah Adebisi Ahmed a, \\ a Department of Science Education, Faculty of Education, University of llorin, Nigeria \\ ${ }^{1}$ ahmed.ma@unilorin.edu.ng/mulkahamed@gmail.com \\ * Corresponding author
}

\begin{tabular}{|c|c|}
\hline ARTICLE INFO & ABSTRACT \\
\hline \multirow[t]{2}{*}{$\begin{array}{l}\text { Article history } \\
\text { Received May 9, } 2020 \\
\text { Revised May 22, } 2020 \\
\text { Accepted June 30, } 2020 \\
\text { Published July 15, } 2020 \\
\text { Keywords } \\
\text { Biology student } \\
\text { Instagram efficacy } \\
\text { Social media }\end{array}$} & $\begin{array}{l}\text { Instagram is one of social media commonly used and has influential power among people } \\
\text { for sharing ideas, instructional media, and social interaction. This study aimed at } \\
\text { examining the efficacy of Instagram on Biology students in University of llorin. This quasi- } \\
\text { experimental study included } 75 \text { undergraduate students of University of llorin, Nigeria } \\
\text { majoring in Biology and Biology Education. Instagram Learning Content Course ware, } \\
\text { Instagram Biology Test, Instagram Biology Marking Guide, and Daily Lesson Plan were } \\
\text { the instruments used in data collection process. Furthermore, the data gained were } \\
\text { analyzed using t-test and ANCOVA. The results revealed that there was significant } \\
\text { difference existed between biology Major and Biology Education students in their learning } \\
\text { achievement }[t(74)=17.852, p<.05] \text {. In contrast, there was no significant difference } \\
\text { between male and female students in learning as they utilized Instagram in learning } \\
\text { process }[F(10,23)=1.541, p>.05] \text {. In conclusion, the more attention is crucial to be pain } \\
\text { for students in their learning process, particularly in the media used. }\end{array}$ \\
\hline & $\begin{array}{l}\text { Copyright } \odot \text { 2020, Ahmed } \\
\text { This is an open access article under the CC-BY-SA license }\end{array}$ \\
\hline
\end{tabular}

How to cite: Ahmed, M. A. (2020). The efficacy of Instagram on biology undergraduate students in University of llorin, Nigeria. JPBI (Jurnal Pendidikan Biologi Indonesia), 6(2), 327-334. doi: https://doi.org/ 10.22219/jpbi.v6i2.12155

\section{INTRODUCTION}

The 21 st-century ushered by rapid and eventual increase of technology has changed cognitive reasoning of people. These technologies affected the way individuals interact. Since the advent of social media, face-to-face communication has reduced. It also offered an interesting arena for people in socializing, sharing of ideas, and giving adequate feedbacks for content creations. Ali (2018) mentioned that Facebook, Twitter, SnapChat, WhatssApp, YouTube, and Instagram are some of social media sites which are more popular among people. Moreover, the media has been a considerable source which influences several fields including education (Bolat, 2018). Albeit that Ting, de Run, and Liew (2016) ascribed that the invention of Instagram was aimed to share photos among the users, but Wong, Chai, and Aw (2017) stressed that Instagram is for educational rationale, which helps learners to generate content and enhances learning. Moreover, Instagram has been a media for sharing learning contents. Fatin, Desa, Embi, and Hashim (2019) expressed that Instagram as a free application can be useful in learning natural objects in biology.

Biology is the scientific study of living organisms including their growth, structure, functions, distribution, taxonomy, and their evolutionary trends. Biology deals with the physiochemical aspect of life. It is broadly divided 
into two main branches. Each of these branches deals with different aspects of life, namely, Zoology and Botany (Stencel \& Proszewska, 2018). Zoology is the study of animals while Botany deals with the study of plants (Alexey, 2020). Thus, biology study improves all aspects of life on earth and helps us to understand ourselves and our environment.

Biology is one of the most popular subjects in Nigerian secondary schools besides Chemistry and Physics. Being a gateway to professions such as medicine, pharmacy, dentistry, agriculture and a host of others, this subject occupies a central position in science world. Therefore, Biology has been seen as one of the most popular science subjects in Nigerian schools. This subject is taught at secondary and tertiary levels of education. Biology as a natural subject is made up of other disciplines such as anatomy, botany, biochemistry, physiology, ecology, and zoology. Therefore, Biology is very important in general education.

The both biology teachers and students have difficulty learning several biological concepts such as genetics, respiration, ecology, photosynthesis and evolution. This fact is supported with the poor performances of West Africa students in biology subject between 2007 and 2016 (The West African Examinations Council, 2016). Their performances were the major concern for science educators in general and biology educators in particular. The trend of student enrolment increased from 2007, but these increments in students' numbers did not reflect the percentages of students that passed the subject. Between year 2007 and 2012, the percentage pass was less than $50 \%$ except for percentage pass in Physics that were more than 50\% between 2009 and 2016 . However, the percentage passes improved from 2012 to 2016. But still, the total students' enrolment between these years cannot be correlated with the percentage passes. The implication is that the rate of failure is still high.

Atotileto, Abimbola, Adefila, and Bello (2015) also buttressed that the performance level for individual science subjects did not show any significant rise except occasionally for chemistry and physics which were a little above $50 \%$. Hence, it was proposed that more teaching strategies should be considered to see if there would be significant rise in student performance in science subjects. Moreover, the rates of enrolment for these subjects were higher compared to the number of candidates that passed the subject. Those were the undergirding reasons to conduct the study of the utilization innovative strategy of Instagram in teaching Biology in terms of Cell Structure and functions, Photosynthesis, Genetics and Ecology. These beneficial to teach Biology in more active way, giving deeper investigative instruction, and allowing students to pursue areas of personal interest.

Many studies projected the supremacy and effectiveness of Instagram in learning. For example, the study of Pujiati, Zahra, and Tamela (2019) examined the use of Instagram to increase students' motivation of learning English language. Likewise, Yadegarfar and Simin (2016) investigated the efficacy of Instagram on learning grammatical structures in Iranian undergraduate and the study revealed that learning with Instagram was positive. Gonulal (2019) concluded that Instagram is a potential media which helps students to improve their language skill. Similarly, Fatin et al. (2019) observed the effectiveness of Instagram-based activities in improving writing skill among the secondary school students. The findings revealed that students' responded strongly to Instagrambased activities which motivates writing and learning. Al-Ali (2016) expressed that Instagram is a powerful tool for handling holiday project, especially for writing activities among learners. In the same vein, Lomicka, Lord, and CALICO (2009) mentioned that Instagram develops learners in both cultural awareness and descriptive language.

However, albeit that the use of Instagram is one of the most commonly used instructional strategies in recent years, it is scanty studies which investigate its usefulness in science education. Aiming to fulfil the gap in the literature and to explore the effects of Instagram, this study observed the efficacy of Instagram on the teaching and learning of Biology among the Biology minor and major undergraduate students in University of llorin, Nigeria.

The findings of this study contribute in providing basic information for teachers and instructors about the implementation of Instagram in learning Biology. Thus, the learning activities will be more student-centered. Furthermore, learning is, therefore, brought about range of goals which involve students to be active in process such as questioning, explaining and discussing which focused on self-instruction using Instagram. Moreover, those will be considerations for policy makers to issue relevant policies to improve educational facilities and serve the better-quality education services.

\section{METHOD}

This quasi-experimental research involved 200 undergraduate students of University of Ilorin, Nigeria who were majoring in Biology and Biology Education. The selection was done based on their academic performances. The students who were ranked in one to 100 level, achieved the CGPA of 3.00 above, had android and vast in the usage of their android phone were the targeted as the audiences. A memo was sent for the students. This 
aimed to find out the students who were interested in this study as considerable as to achieve ethical consent. As the results, there were only 75 undergraduate biology students involved. The students were comprised of 35 males and 40 females. These students were divided into experimental and control groups.

There were four instruments used in this study i.e. Instagram Learning Content Course-ware (ILCC), the validated Instagram Biology Test (IBT), Instagram Biology Marking Guide (IBMG), and Daily Lesson Plan on the Instagram Biology. The Biology Instructional Materials (BIM) was given for the control (conventional) group. Meanwhile, the Instagram Learning Content Course-ware (ILCC) was made up from the prepared topics for four weeks in which the materials were Cell Structure and Function, Photosynthesis, Genetics and Ecology. It was developed with the help of the Head of Department, Science Education, University of llorin. It was later presented to a Biology professor, a lecturer in the department of Educational Technology as well as Computer Science professor to be validated in both face and content.

The validated Instagram Biology Test (IBT) consisted of 100 multiple choice objective items taken from the validated Joint Admission and Matriculation Board (JAMB). The 100 items were extracted from the last five years questions based on the topics taugh in which each question was followed with five options (A-E) as the possible answers. The students were instructed to carefully pick the correct answers in shading any letters from "A" to " $\mathrm{E}$ " given. The Instagram Biology Test (IBT) was first given to the 75 students as a pre-test which later after the thorough treatment was re-arranged and given for post-test.

The experimental aims, objectives, procedures including the modality were written in the experimental manual exhibited for students. The Instagram Learning Content comprised of six weeks topics. The first week was for familiarizing the learners with Instagram and confirming the suitability of the android devices, for spacing, speeding and the work. The experimental group students were asked to link up with the teacher via internet using their android on weekly bases as the instructor posts on their time line. Researcher posted biological pictures and texts which were followed with a request for students to do the test. After inviting the students to follow the test, the researcher clicked the "poll" to gather students' responses and evaluated the students weekly.

Meanwhile, the control group students were taught by researcher's assistant with the topics of Cell Structure and Function, Photosynthesis, Genetics, and Ecology using conventional strategy. After the completion of material delivering, the paper-based test was given as the post-test to the both groups. The test was well conducted under the supervision of the researchers' assistant. The answered test was collected for marking. The 100 -scale score was used to make students' post-test scores. The marking results were analyzed using IBM SPSS Statics, version 21 at 0.05 alpha level.

\section{RESULTS AND DISCUSSION}

The implementation of Instagram in biology learning activities was conducted in the both experimental and control groups. The analysis results of before and after the treatment given are served in Table 1. It can be obviously seen that there was significant different of students' ability before and after Instagram implementation $[t(74)=17.852, p<.05]$. To be more detail, the mean values between pre-test and post-test shows the decrease of students' score.

Table 1. The results of paired samples t-test of students' scores

\begin{tabular}{clccccc}
\hline Variables & Number & Mean & Std. Deviation & Df & T & sig. (2- tailed) \\
\hline Pre test & 75 & 75.07 & 13.04 & 74 & 17.852 & .000 \\
Post test & 75 & 46.80 & 5.31 & & & \\
\hline
\end{tabular}

This finding is contradict with several previous researches done. Akhiar, Mydin, and Kasuma, (2017), as well as Handayani, Cahyono, and Widiati (2018) revealed that Instagram affected significantly students' achievement in positive way. The others stated that Instagram improves students' learning motivation (Soviyah \& Etikaningsih, 2018), writing skill (Wahyudin \& Sari, 2018), and language skill (Erarslan, 2019; Wong et al., 2017). However, the significant decrease occurred in this study was predicted because of no separation between two groups as the data was analyzed. Thus, the students' scores of the both experimental and control groups were mixed.

To gain more detail investigation, the ANCOVA test was conducted to test if there is significant difference between experimental and control group. The results of the test are presented in Table 2. It depicts that there was no significant different found between experimental and control group $[F(10,25)=2.129, p>.05]$. Interestingly, albeit that there was no significant different between the two groups treated, but the mean values of pre-test and post-test scores show the improvement of students' achievement. Moreover, the significance value show the 
close value to .05 . This means that the difference between the both observed classes were close to significant as well.

Table 2. The results of ANCOVA test of students' scores between experimental and control groups

\begin{tabular}{llllll}
\hline Source & Type III Sum of Squares & Df & Mean Square & F & Sig. \\
\hline Corrected Model & $2595.834^{a}$ & 11 & 235.985 & 2.269 & .044 \\
Intercept & 3046.446 & 1 & 3046.446 & 29.288 & .000 \\
Pre test & 14.681 & 1 & 14.681 & .141 & .710 \\
Post test & 2214.173 & 10 & 221.417 & 2.129 & .061 \\
Error & 2600.436 & 25 & 104.017 & & \\
Total & 220126.000 & 37 & & & \\
Corrected Total & 5196.270 & 36 & & & \\
\hline
\end{tabular}

a. R Squared $=.500$ (Adjusted R Squared $=.279$ )

Following the ANCOVA test to answer the significant difference between the experimental and control group, the ANCOVA test was also done to ensure the significant difference of biology concept mastering between male and female students. The results of the test are served in Table 3 . It is clear that no significant different exists between male and female students in mastering biology concept by implementing Instagram $[F(10,23)=1.541$, $p>.05]$ as the learning media.

Table 3. Analysis of covariance of male and female students taught with Instagram

\begin{tabular}{llllll}
\hline Source & Type III Sum of Squares & Df & Mean Square & F & Sig \\
\hline Corrected Model & $698.530^{\mathrm{a}}$ & 11 & 63.503 & 1.471 & .209 \\
Intercept & 1106.035 & 1 & 1106.035 & 25.616 & .000 \\
Pre test & 26.763 & 1 & 26.763 & .620 & .439 \\
Post test & 665.417 & 10 & 66.542 & 1.541 & .188 \\
Error & 993.070 & 23 & 43.177 & & \\
Total & 71938.000 & 35 & & & \\
Corrected Total & 1691.600 & 34 & &
\end{tabular}

The insignificant difference occurred was assumed because of other unobserved variables existed surrounding the learning processes. It has been well known that many factors interfere students' performance (Mosha, 2014). Duruji, Azuh, and Olarenwaju (2014) concluded that learning environment and external examination influence students' performances. Sunday and Kola (2014) reported that the involvement of teachers is related to the outcome of students' academic performance. The others proposed the other factors affect students' performance such as nature, motivation, learning strategies (Gbollie \& Keamu, 2017)

In term of gender difference, Bermudez, Prasad, Alsadoon, and Hourany (2016) revealed that female students in both private and public schools considered using Instagram as an integral part of their learning. Contrarily, the findings of Huang and Su (2018) confirmed that the use of Instagram of professional training in both male and female in excess causes addiction.

Based on the above discussion, the use of Instagram in learning process must be considered based on study case of the object treated. Essentially, the established regulation to manage this media is compulsory. Hence, targeted learning goals will be successfully enacted.

\section{CONCLUSION}

The result of this study concluded that Instagram has positive effect on the teaching and learning of Biology topics including Cell Structure and Function, Photosynthesis, Genetics and Ecology. Yet, to get significant improvement of students' achievement, the further treatment and regulation are needed. There was no significant different between male and female students' score after treated using Instagram in learning process. On the bases of findings and conclusion drawn, the study suggested the following (1) students need to be encouraged on the use of Instagram to better their learning irrespective of whether they are Biology major or Biology Education; (2) Both male and female students should equally be encouraged to use Instagram so as to enhance their effective learning of Biology topics. 


\section{REFERENCES}

Akhiar, A., Mydin, A.-A., \& Kasuma, S. A. A. (2017). Students' perceptions and attitudes towards the use of Instagram in English Language writing. Malaysian Journal of Learning and Instruction (MJLI), Special issue on Graduate Students Research on Education, 47-72. Retrieved from: http://mjli.uum.edu.my/ images/specialissue/2017/A3.pdf

Al-Ali, S. (2016). Embracing the selfie craze: Exploring the possible use of Instagram as a language mlearning tool. Issues and Trends in Educational Technology, 2(2), 1-16. doi: https://doi.org/10.2458/azu_itet_ v2i2_ai-ali

Alexey, S. (2020). Introduction to Botany. Minot State University. Retrieved from: http://ashipunov.info/ shipunov/school/biol_154/textbook/intro_botany.pdf

Ali, L. (2018). The Influence of Information Technology on Student's Behavioural Nature in the Class Room. Asian Journal of Education and Training, 4(2), 102-107. doi: https://doi.org/10.20448/journal.522.2018. 42.102.107

Atotileto, Z. B., Abimbola, I. O., Adefila, E. J., \& Bello, Z. . (2015). Science process skills perceived difficult to teach by upper basic science teachers in Kwara State. School od Science, Kwara State College of Education. Retrieved from: http://ptcdn.com.ng/kwcoeiloX_1hT/staff/publications/bello_z_z5z4/03nfb.pdf

Bermudez, C. M., Prasad, P. W. C., Alsadoon, A., \& Hourany, L. (2016). Students perception on the use of social media to learn English within secondary education in developing countries. IEEE Global Engineering Education Conference, EDUCON, 10-13-April-2016, 968-973. doi: https://doi.org/10.1109/ EDUCON.2016.7474668

Bolat, Y. (2018). Research on the Use of Social Media Networks by Teacher Candidates. Journal of Curriculum and Teaching, 7(1), 147. doi: https://doi.org/10.5430/jct.v7n1p147

Duruji, M., Azuh, D., \& Olarenwaju, F. (2014). Learning environment and academic performance of secondary school students in external examinations: A study of selected schools in Ota. EDULEARN14 Proceedings, 5042-5053. Retrieved from: https://library.iated.org/view/DURUJI2014LEA

Erarslan, A. (2019). Instagram as an education platform for EFL learners. TOJET: The Turkish Online Journal of Educational Technology, 18(3), 54-69. Retrieved from: http://www.tojet.net/articles/v18i3/1835.pdf

Fatin, A., Desa, M., Embi, M. A., \& Hashim, H. (2019). The Effects of Instagram Based Activities in Improving Secondary School Students' Writing Skill. International Journal of Research and Innovation in Social Science, III(IV), 2454-6186. Retrieved from: https://www.rsisinternational.org/journals/ijriss/DigitalLibrary/volume-3-issue-4/339-363.pdf

Gbollie, C., \& Keamu, H. P. (2017). Student academic performance: The role of motivation, strategies, and perceived factors hindering Liberian Junior and Senior High School students learning. Education Research International, 2017, 1-11. doi: https://doi.org/10.1155/2017/1789084

Gonulal, T. (2019). The use of instagram as a mobile-assisted language learning tool. Contemporary Educational Technology, 10(3), 309-323. doi: https://doi.org/10.30935/cet.590108

Handayani, A. D., Cahyono, B. Y., \& Widiati, U. (2018). The use of Instagram in the teaching of EFL writing: Effect on writing ability and students' perceptions | Handayani | Studies in English Language Teaching. Studies in English Language Teaching, 6(2), 112-126. doi: https://doi.org/10.22158/selt.v6n2p112

Huang, Y.-T., \& Su, S.-F. (2018). Motives for Instagram use and topics of interest among young adults. Future Internet, 10(8), 77. doi: https://doi.org/10.3390/fi10080077

Lomicka, L., Lord, G., \& CALICO. (2009). The next generation : social networking and online collaboration in foreign language learning - Catalog - UW-Madison Libraries (Vol. 8). CALICO, Texas State University. Retrieved from: https://search.library.wisc.edu/catalog/9910152098802121

Mosha, M. A. (2014). Factors affecting students' performance in English Language in Zanzibar rural and urban secondary school. Journal of Education and Practice, 5(35), 64-76. Retrieved from: https://www.iiste.org/ Journals/index.php/JEP/article/view/17455/17714

Pujiati, H., Zahra, \& Tamela, E. (2019). The use of Instagram to increase students' motivation and students' competence in learning English. Proceedings of the 1st International Conference on Education Social Sciences and Humanities (ICESSHum 2019), 651-656. doi: https://doi.org/10.2991/icesshum-19.20 19.103

Soviyah, S., \& Etikaningsih, D. R. (2018). Instagram use to enhance ability in writing descriptive texts. Indonesian EFL Journal, 4(2), 32-38. doi: https://doi.org/10.25134/ieflj.v4i2.1373

Stencel, A., \& Proszewska, A. M. (2018). How research on Microbiomes is changing Biology: A discussion on 
the concept of the organism. Foundations of Science, 23(4), 603-620. doi: https://doi.org/10.1007/ s10699-017-9543-x

Sunday, S., \& Kola, J. (2014). Improving Students' Academic Performance in Nigerian Schools: the Role of Teachers. International Journal of Research in Humanities and Social Studies, 1(2), 1-6. Retrieved from: https://www.ijrhss.org/pdf/v1-i2/1.pdf

The West African Examinations Council. (2016). The West African Senior School Certificate Examination (WASSCE). Retrieved from: waecgh.org

Ting, H., de Run, E. C., \& Liew, S. L. (2016). Intention to Use Instagram by Generation Cohorts: The Perspective of Developing Markets. Global Bussiness and Management Research, 8(1), 43-55. Retrieved from: https://search.proquest.com/openview/c4d14301258f457496efcb403f46ee34/1?pq-origsite=gscholar $\& \mathrm{cbl}=696409$

Wahyudin, A. Y., \& Sari, F. M. (2018). The effect of Instagram on the students' writing ability at undergraduate level. The 1st International Conference on English Language Teaching and Learning (1st ICON-ELTL), 1-10. Retrieved from: https://www.researchgate.net/publication/335320426_THE_EFFECT_OF_INSTA GRAM_ON_THE_STUDENTS'_WRITING_ABILITY_AT_UNDERGRADUATE_LEVEL

Wong, L. H., Chai, C. S., \& Aw, G. P. (2017). Seamless language learning: Second language learning with social media. Comunicar, 25(50), 9-20. doi: https://doi.org/10.3916/C50-2017-01

Yadegarfar, H., \& Simin, S. (2016). Effects of using Instagram on learning grammatical accuracy of word classes. International Journal of Research Studies in Educational Technology, 5(2). Retrieved from: https://www.learntechlib.org/p/173362/ 